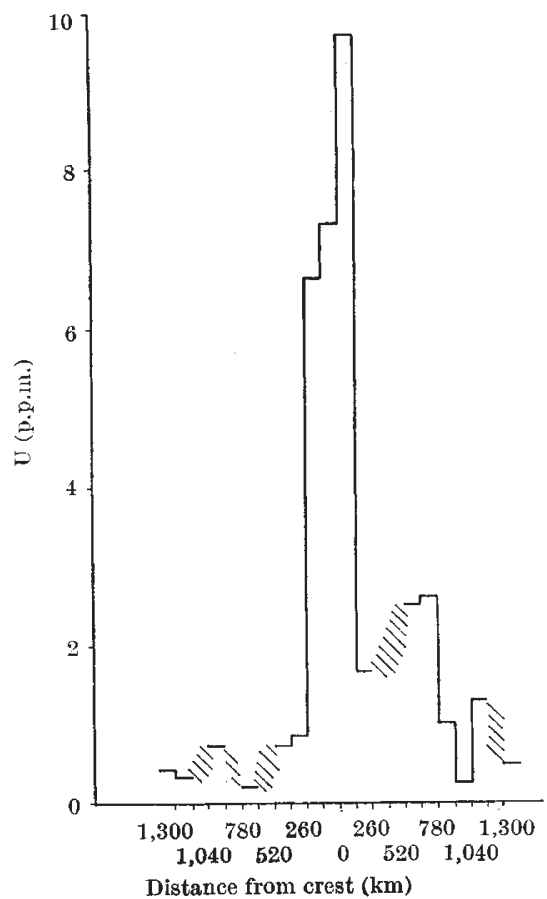

Fig. 2. Variation of $U$ in deep sea sediments with distance from the crest of the East Pacific Rise.

constituents ( $\mathrm{Fe}, \mathrm{Mn}, \mathrm{V}, \mathrm{P}, \mathrm{Ba}, \mathrm{Hg}$, As and $\mathrm{Cd}$ ) suggests a similar volcanic origin for $\mathrm{U}$.

We thank Mrs M. Riera for assistance with the $\mathrm{CaCO}_{3}$ determinations, and A. Horowitz and T. Middleton for help in the $U$ analyses. This work was supported in part by the US National Science Foundation, the US Atomic Energy Commission and the US Office of Naval Research. David E. Fisher

Institute of Marine Sciences, KURT Bostrom

University of Miami,

Miami, Florida 33149 .

Received May 27, 1969.

1 Bestrom, K. and Peterson, M. N. A., Econ. Geol., 61, 1258 (1966).

2 Bostrom, K., and Peterson, M. N. A., Marine Geol. (in the press, 1969).

${ }^{3}$ Bostrom, K., Peterson, M. N. A., Joensuu, O., and Fisher, D. E., J. Geophys. Res. (in the press).

- Bostrom, K., and Fisher, D. E., Cosmochim. Acta (in the press, 1969).

5 Bostrom, K., and Valdes, S., Lithos (in the press).

- Ku, T. J Geophys. Res, 70, 3457 (1965).

' Veeh, H. H., Earth Plan. Sci, Lett., 3, 145 (1967).

Fleischer, M., Geochim. Cosmochim. Acta, 33, 65 (1969).

- Flanagan, F. J., Geochim. Cosmochim. Acta, 33, 81 (1969).

\section{East African Rift System}

THE article entitled "How far does the Rift System extend through Africa?" by Fairhead and Girdler ${ }^{1}$ is of great interest to geologists who are studying the structure of the African Pre-Cambrian platform, because the exact relocation of the epicentres of earthquakes could havo great significance if related to known geological features. For example, in addition to the relationships suggested in the communication, the cluster of epicentres shown in their Fig. 1 at about latitude $14^{\circ} \mathrm{S}$, longitude $22^{\circ} \mathrm{E}$, lies on the south-westward projection of the Upemba rift beneath the overburden of the Okavango basin, and, by reference to shect 5 of the new tectonic map of Africa ${ }^{2}$, also lies along the limit between the ancient Congo Craton and the Katangan orogenic belt; it may thus indicate recent continuation of movement along this fundamental lineament brought into prominence by Kennedy ${ }^{3}$. A sccond point of great interest is the NNE-SSW trending line in South Africa of six epicentres which is parallel to and about $300 \mathrm{~km}$ inland from the eastern coast. 'This may be found to indicate recent movement on a lineament continuing the Shire and Urema grabens (ref. 2, sheet 9) to the south-south-west. Other important relationships will be apparent to geologists familiar with southern Africa.

The confirmation of continued movement on the NE-SW Lako Mweru graben is also of value. The existence of these rift faults has been questioned, but was substantiated by Cahen in a standard work of reference (ref. 4, Fig. 93 and page 468), and the faults were shown in Fig. 1 of a recent article ${ }^{5}$. The continuation of this segment of the rift system in an $\mathrm{N}-\mathrm{S}$ alignment along longitude $26^{\circ} \mathrm{E}$, as suggested by Fairhead and Girdler, seems doubtful because this line would cross many NE-SW tectonic features. It is important to note, however, that such an alignment would follow approximately the location of the monocline defining the eastern margin of the Okavango and Kalahari basins, and may indicate the continued deepening of these Tertiary and Quaternary features.

The East African rift system is now the centro of much research and the modern and very precise geophysical investigations in progress promise to make a most valuable contribution to its three-dimensional depiction, but the article by Fairhead and Girdler ${ }^{1}$ indicates the urgency of defining what is meant by the term "rift system", and also emphasizes the value of furthering close collaboration between geophysical and geological researchers.

R. B. MCCONNELI

Streatwick,

Streat near Hassocks,

Sussex.

Received March 26, 1969.

${ }^{1}$ Fairhead, J. D., and Girdler, R. W., Nature, 221, 1018 (1969).

2 Choubert, G., and Faure-Muret, A., International Tectonie Map of Africa. $1: 5,000,000$ (Association des Services Géologiques Africains-Unesco, Paris, 1968).

${ }^{3}$ Kennedy, W. Q., in Salt Basins around Africa (Inst. of Petroleum, London, 1965).

4Cahen, L., Géologie du Congo Belge (Vaillant-Carmanne, Liège, 1954).

${ }^{5}$ McConnell, R. B., Nature, 215, 578 (1967).

\section{Age and Insect Fauna of the Dimlington Silts, East Yorkshire}

The Dimlington Silts are a series of laminated silts and sands, exposed near the foot of Dirnlington Cliff ( $T A$ 391217 ). They occupy hollows on the surface of the Saalo (Basement) till, and are overlain by the Weichsel (Drab) till and have been interpreted ${ }^{1}$ not as interglacial deposits but as interstadial deposits of the Würm (Weichsel) glaciation, with the overlying Drab, Purple and Hessle tills belonging to the Main Würm (that is, Upper Pleniglacial $^{2}$ ).

Fossils in the silts include the remains of moss; this was considered suitable for radiocarbon dating, because it is well preserved, is indigenous to the deposit, was buried rapidly, and has been sealed since deposition of the Drab till. Samples were collected on two occasions from an exposure at $T A 386224$ (about $200 \mathrm{~m}$ ESE of Cliff Farm); they were taken from the same bedding plane, but were pre-treated in different ways, analysed in different laboratories, and their ${ }^{12} \mathrm{C} /{ }^{14} \mathrm{C}$ ratios were determined in different forms (as $\mathrm{CO}_{2}$ and $\mathrm{CH}_{4}$ respectively). The results were 